\title{
Poverty erodes dignity: perspectives of low income female caregivers in South Africa
}

Dignity is a foundational value in South Africa's Constitution and is also experienced as a psycho-social phenomenon. Dimensions of dignity were explored with almost two hundred low income female caregivers and the impact of poverty on dignity was examined.

\section{Key points}

- Dignity is experienced in many different ways that are both intensely personal and relational. Dignity is linked to women's sense of identity, and the dimensions of worthiness, self-esteem, self-respect and autonomy are important aspects of dignity in practice.

- Low income women provided accounts of how poverty was experienced as erosive of all of these dimensions of dignity.

- In the absence of sufficient employment opportunities or comprehensive social security, many of the ways in which low income women attempt to survive poverty were experienced as erosive of dignity. Examples included dependence on relatives, undertaking demeaning casual work in the community, begging, and transactional sex.

- These findings were supported by responses to a social attitudes survey in which $81 \%$ of adults agreed that 'poverty erodes dignity'.

The research

By Gemma Wright, Michael Noble, Phakama

Ntshongwana, David Neves and Helen Barnes.

A collaboration between the Centre for the Analysis

of South African Social Policy at the University of

Oxford, the Institute for Poverty, Land and Agrarian

Studies at the University of the Western Cape, and

$\mathrm{E} \cdot \mathrm{S} \cdot \mathrm{R} \cdot \mathrm{C}$

ECONOMIC

\& SOCIAL

RESEARCH

COUNCI L

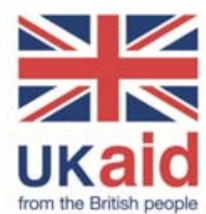

Research jointly supported by the ESRC and DFID

POLICY BRIEF 1

JULY 2014 


\section{BACKGROUND}

The South African Constitution states that 'Everyone has inherent dignity and the right to have their dignity respected and protected'. How is dignity experienced in practice? And does poverty have an impact on dignity?

\section{Why focus on dignity?}

The Universal Declaration of Human Rights introduces the recognition of the inherent dignity of all people as a foundation of freedom, justice and peace in the world. Dignity plays a prominent role in South Africa's Constitution, both as a foundational value and a right. Dignity can also be considered as a psycho-social phenomenon and at times these two notions of dignity ('dignity as principle' and 'dignity in practice') can seem disconnected. In this study we explored the linkages by investigating the impact of poverty on dignity, and in particular the extent to which dignity is experienced as violable.

\section{Methodology}

Thirty-six focus groups and 16 in-depth interviews were undertaken in the Eastern Cape and Western Cape in South Africa with low income female caregivers. Just under 200 women took part in the focus groups. Interviews were also held with senior policy makers in government, and social attitudes were explored more broadly in relation to dignity, poverty and social security using data from the HSRC's South African Social Attitudes Survey.

\section{Dimensions of dignity in practice}

Worthiness - women spoke of the importance of feeling valued or worthy within their families and communities. This dimension of dignity is compromised by unemployment and by experiences of sexism and racism.

Self-respect - this was identified as a pre-requisite to earning the respect of others and reference was also made to enacting 'respectable behaviour'.

Self-esteem - most prominent was the importance of role preservation as caregiver of children. Dignity was also described by women as being intrinsically linked to their sense of humanity.

Autonomy - paid work was seen as the main route to attaining dignity, as the income enables women to meet their own material needs, those of their children, and their wider family. However, the conferment of dignity is not automatically associated with paid work, and several spoke of how their dignity was so compromised when in insecure, poorly-paid or precarious work that they left their jobs.

"I am who I am and at the core of that is my dignity." 


\section{Poverty erodes dignity}

Accounts were given of the negative impact of poverty on women's self-esteem, ranging from despondency to desperation and despair. The inability to fulfil the role of caregiver due to poverty resulted in some women describing their dignity as 'crushed' and 'destroyed'.

"As a mother and in relation to my role as a mother, I have no dignity. In my child's eyes I am not dignified because I cannot provide for him. Even in comparison to other mothers, I have no dignity because I can see they can provide for their children much better than I can. My child can see this too."

Women described how poverty reduces their standing within the community, and how this negatively impacts on their dignity.

"I live my life with dignity but am not living a dignified life overall. Poverty takes away all my dignity. Everybody in my community knows that I'm poor, that I'm single struggling with children whose father doesn't care for them. When I walk into somebody's house, already they think I have come to ask for something, for money or food."

Poverty leads to strained family relations. Accounts were given of women being treated contemptuously within their families, being insulted, excluded from decision-making, and treated as a burden. People spoke of there being no dignity in poverty, and the indignity of having to depend on others to meet their own material needs.

"My family takes decisions without me because they know I don't have money, nothing to contribute. Where's my dignity in all that?"

The participants did not present themselves as passive victims but as people who have to fight each day to survive. The cruel reality was exposed that many of the strategies used by the focus group participants to survive poverty in the context of high unemployment were experienced as being detrimental to dignity.

"Poverty is humiliating. When you go and beg for food, first of all you're hungry, at that very moment, you're really hungry. You smile and laugh at anything they say even if it's not funny, maybe it's even a jab at you, but because you're begging for survival, you have to act stupid. So yes, poverty can kill one's dignity. You may or may not get food. If you don't you go on to the next house. When you walk out of these houses, you heart is in anguish." 


\section{Conclusion}

This aspect of the study revealed many ways in which dignity is negatively affected by poverty, in terms of the women's sense of worthiness, self-respect, self-esteem and autonomy. As poverty violates dignity, and dignity is a foundational value and a right in the Constitution, the eradication of poverty should be at the forefront of social and economic policy. Subsequent policy briefs consider the role of social security in protecting and respecting dignity.

\section{About the project}

A group of researchers from the Centre for the Analysis of South African Social Policy at the University of Oxford in the UK, the Institute for Poverty, Land and Agrarian Studies at the University of the Western Cape in South Africa, and the South African Human Sciences Research Council undertook a research project between 2011 and 2014 entitled 'Lone Mothers in South Africa - The role of social security in respecting and protecting dignity'. It was funded by the Economic and Social Research Council and the UK Department for International Development (ESRC Ref ES/I033130/1).

\section{For further information}

- Policy Brief 2: South Africa's Child Support Grant and the dignity of female caregivers

- Policy Brief 3: The Role of Social Security in Respecting and Protecting the Dignity of Lone Mothers in South Africa: Summary of Findings and Recommendations

The full report, The Role of Social Security in Respecting and Protecting the Dignity of Lone Mothers in South Africa: Final Report by Gemma Wright, Michael Noble, Phakama Ntshongwana, David Neves and Helen Barnes, is available at:

http://www.casasp.ox.ac.uk/docs/Dignity_final_report_120714.pdf. Or for further information contact Dr Gemma Wright by email gemma.wright@saspri.org or phone $+27(0) 218136435$.
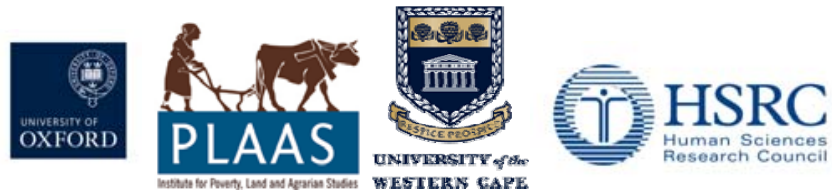